\title{
Reduced endogenous nitric oxide in the exhaled air of smokers and hypertensives
}

\author{
J. Schilling*, P. Holzer*, M. Guggenbach*, D. Gyurech**, K. Marathia*, S. Geroulanos*
}

\begin{abstract}
Reduced endogenous nitric oxide in the exhaled air of smokers and hypertensives. $J$ Schilling, P. Holzer, M. Guggenbach, D. Gyurech, K. Marathia, S. Geroulanos. CERS Journals Ltd 1994.

ABSTRACT: We wanted to determine whether the production of endogenous nitric oxide (NO) is affected by cigarette smoking and various pathological conditions.

Endogenously produced NO was measured by chemiluminescence in the exhaled air of 81 healthy volunteers (21 nonsmoking females (NSF), 12 smoking females (SF), 24 nonsmoking males (NSM) and 24 smoking males (SM)) and 38 patients (10 with hypertension, 10 intra- and 10 postoperative, 5 with renal failure and 3 with sepsis) entered the protocol. Subjects inspired from a NO-free air supply, which was also used to calibrate the NO-analyser.

Endogenous NO production of volunteers was $18 \pm 8$ per billion (ppb) depending on smoking habits. In exhaled air of NSF, NO concentration was $21 \pm 7 \mathrm{ppb}$, in SF $16 \pm 6 \mathrm{ppb}$, in NSM 19 $\pm 8 \mathrm{ppb}$ and in SM $15 \pm 6 \mathrm{ppb}$. Differences between smokers and nonsmokers were significant. Increased diastolic blood pressure was noted in SM compared to NSM (86 \pm 7 versus $78 \pm 7 \mathrm{mmHg})$. Patients with documented and treated hypertension (systolic and diastolic blood pressure: $141 \pm 18$ and $82 \pm 9 \mathrm{mmHg}$ ) exhaled 13.7 $\pm 5.3 \mathrm{ppb}$ NO; hypertensive males $10 \pm 2 \mathrm{ppb}$ NO and females $17 \pm 5 \mathrm{ppb}$ NO. In patients with renal failure NO concentration in exhaled air was $20.2 \pm 6.8$ ppb before and 19.8 $\pm 6.4 \mathrm{ppb}$ one hour after the onset of dialysis. In patients undergoing major surgery NO concentration was $5.6 \pm 2.5 \mathrm{ppb}$ intra- and $10.3 \pm 3.5 \mathrm{ppb}$ postoperatively. In three mechanically ventilated patients with documented septic syndrome, exhaled NO was $29.3 \pm 24 \mathrm{ppb}$.

We conclude that smokers and patients with hypertension exhale significantly less NO than healthy volunteers. This suggests that exhaled NO can be used as a marker and therapeutic target in disease.

Eur Respir J., 1994, 7, 467-471.
\end{abstract}

Nitric oxide acts as an endogenous vasodilator molecule [1-4]. It is synthesized from L-arginine, largely by the "organ endothelium" $\left(6 \times 10^{23}\right.$ cells, 1,000 square meters surface, $1.5 \mathrm{~kg}$ weight) and various other tissues, as well as cells in the alveoli and airways $[1,5]$. Its plasma half-life is only a few seconds $[6,7]$.

As NO acts as an endogenous gas-vasodilator [1-4] it is possible that it is involved in the physiological control of systemic blood pressure. For this reason, methods to assess endogenously produced NO are required. Currently, no blood gas analysers for NO are available. Exhaled air may be a logical medium to evaluate endogenously produced NO, although exhaled air-concentrations may not reflect systemic blood concentrations, due to its reactivity and local lung production.

The aim of this study was to evaluate endogenously produced NO in exhaled air, focusing on differences between several population groups. In contrast to other studies [8], subjects inspired from a NO-free air supply, as ambient air is contaminated with various amounts of NO.

\begin{abstract}
Depts of *Surgery and **Social and Preventive Medicine, University Hospital of Zurich, Zurich, Switzerland.
\end{abstract}

Correspondence: S. Geroulanos Dept of Surgical Intensive Care Onassis Center

Leof. Syngrou Av. 356

GR - 17674 Kallithea

Athens

Keywords: Chemiluminescence endogenous nitric oxide exhaled air hypertension smoking

Received: May 131993

Accepted after revision October 291993

\section{Materials and methods}

In this cohort trial, endogenously produced $\mathrm{NO}$ was measured by chemiluminescence in the expired air of 119 subjects. As ambient air contains a high and variable NO concentration (6-192 ppb) a standardized, purified $\mathrm{NO}, \mathrm{NO}_{2}, \mathrm{CO}, \mathrm{CO}_{2}$ and ozone free air was prepared for inhalation by our study population. Under a constant pressure, normal hospital air passed a water filter, a $\mathrm{CO}-\mathrm{CO}_{2}$ converter (heated palladium), a purafil-converter (granular aluminium oxide and potassium permanganate) to oxidize $\mathrm{NO}$ to $\mathrm{NO}_{2}$, and finally an active-coal filter to absorb $\mathrm{CO}_{2}$ and $\mathrm{NO}_{2}$ molecules. The purified gas mixture was accumulated in flexible, empty polyethylene reservoirs and analysed for NO after production and immediately before use. An upper limit of up to $5 \mathrm{ppb}$ NO was accepted. For all NO analyses, the commercial instrument CLD 700 AL (ECO Physics, 8635 Dürnten, $\mathrm{CH})$ was utilized. Calibration was performed weekly using a diluted calibration-gas-mixture of exactly 900 ppb. Fifty to 100 parts per million (ppm) NO were 
diluted with a dry, $\mathrm{NO}, \mathrm{NO}_{2}, \mathrm{CO}, \mathrm{CO}_{2}$ and ozone free $\mathrm{N}_{2} \mathrm{O}_{2}$ mixture (1:100-500). For calibration only Tefloncoated tube-systems were used. The minimal detectable NO concentration was $1 \mathrm{ppb}$, corresponding to 0.000,0001 volume-percent. Calibration and all measurements were performed in the same chamber under constant conditions.

\section{Preliminary experiments}

To determinate whether the polyethylene material of the specially manufactured reservoirs and tube systems interferes with NO measurements, three tubes and three reservoirs were filled with $5 \mathrm{ppb}$ NO. After 6 and $12 \mathrm{~h}$, NO concentration was still $5 \mathrm{ppb}$ in the tubes and reservoirs, and after $24 \mathrm{~h} 8 \mathrm{ppb}$ in two of the reservoirs. The same experiment was performed with $30 \mathrm{ppb}$, with similar results $( \pm 2 \mathrm{ppb})$. In a third experiment, a reservoir was filled with $16 \mathrm{ppb} \mathrm{NO}$ at a temperature of $26^{\circ} \mathrm{C}$, heated once to $40^{\circ} \mathrm{C}$ and cooled down once to $12^{\circ} \mathrm{C}$ for $30 \mathrm{~min}$. In these experiments, no changes were observed. In a fourth experiment, the role of the diameter and length of inspiratory and expiratory tubes were evaluated. We found no differences in the NO concentration using tubes up to $2 \mathrm{~m}$ long and up to $3 \mathrm{~cm}$ wide. In addition, compressed standard hospital-roomair $\left(\mathrm{N}_{2} / \mathrm{O}_{2}\right)$ was analysed. NO concentration varied over 7 days (27.4 $\pm 13 \mathrm{ppb})$, depending on the weather and possibly on the traffic conditions in the vicinity of the hospital. Mean NO concentration of normal hospital-room-air was $54 \pm 58 \mathrm{ppb}$, with a minimum of 6 and a maximum of $192 \mathrm{ppb}$.

Under normal barometric pressure (965 mbar) at a temperature of $20^{\circ} \mathrm{C}$, water and $\mathrm{CO}_{2}$ absorb $\mathrm{NO}$, a process known as "quenching". This results in $2 \%$ lower NO determination than true levels. As the sensivity of NO detection in the very low range varies by almost $10 \%$, quenching-uncertainty is unlikely to be very important.

\section{Volunteers and Patients}

All volunteers breathed normally, in a comfortable position for 5-10 min (30-50 l), inhaling the purified air from the first reservoir, with nose closed, via a T-airvalve and exhaling NO-containing air into a second flexible, empty reservoir. Reservoirs containing NO-free air were tested for NO immediately before use. At the end of the experiment, NO concentration in the second reservoir was analysed. To evaluate NO concentration in exhaled air of postoperative, hypertensive and dialysed patients, reservoirs with NO-free air were first analysed and then transported from the laboratory to the wards. Patients breathed normally for 5-10 min, inhaling the NO-free air from the first reservoir and exhaling their NO-containing air into a second empty reservoir as did the volunteers. To avoid a possible quenching of $\mathrm{NO}$ by $\mathrm{CO}_{2}$, oxygen or water in the reservoirs containing volunteers' or patients' exhaled air, a water absorber was installed in the proximal expiratory port, and reservoirs were immediately transported back to the laboratory and analysed. In septic and intraoperative patients, purified air was not applicable due to mechanical ventilation. In these patients, routine inhaled air and exhaled air were collected in a comparable amount $(30-50 l)$ at a minimal distance from the patient, transported to the laboratory and analysed immediately.

Eighty one healthy volunteers (33 females and 48 males) were allocated to four groups: nonsmoking females $(\mathrm{n}=21)$; smoking females $(\mathrm{n}=12)$; nonsmoking males $(n=24)$; and smoking males $(n=24)$. Volunteers with an asthmatic component, hyper- or hypotension, or infections within the previous two weeks were excluded. Smokers were obliged not to smoke within $2 \mathrm{~h}$ prior to NO measurements. Characteristics of volunteers are shown in table 1.

In addition to healthy volunteers, a total of 38 patients were recruited for the study. All patients or their legal representatives provided an oral informed consent. In 10 patients with documented hypertension, NO was analysed under medication. In 5 patients with renal failure (postpartum, membranous glomerular disease, chronic kidney rejection and immunoglobulin $\mathrm{A}(\operatorname{Ig} \mathrm{A})$-nephritis), NO was analysed before and $1 \mathrm{~h}$ after the onset of haemodialysis. In 10 mechanically-ventilated, anaesthetized patients undergoing major surgery, NO was measured intraoperatively, $1 \mathrm{~h}$ after the induction of anaesthesia. In these

Table 1. - NO levels and characteristics of healthy volunteers

\begin{tabular}{lrrrrrrrrc}
\hline Group & $\begin{array}{c}\text { Age } \\
\text { yrs }\end{array}$ & $\begin{array}{c}\text { Weight } \\
\mathrm{kg}\end{array}$ & $\begin{array}{c}\text { Height } \\
\mathrm{cm}\end{array}$ & $\begin{array}{c}\text { Pack } \\
\text { yrs }\end{array}$ & $\begin{array}{c}\text { HR } \\
\mathrm{b} \cdot \mathrm{min}^{-1}\end{array}$ & $\begin{array}{c}\text { MAP } \\
\mathrm{mmHg}\end{array}$ & $\begin{array}{c}\text { SBP } \\
\mathrm{mmHg}\end{array}$ & $\begin{array}{c}\text { DBP } \\
\mathrm{mmHg}\end{array}$ & $\begin{array}{c}\text { NO } \\
\mathrm{ppb}\end{array}$ \\
\hline Total (n=81) & 30 & 67 & 174 & & 71 & 95 & 124 & 80 & 18 \\
& \pm 10 & \pm 11 & \pm 9 & & \pm 8 & \pm 7 & \pm 10 & \pm 8 & \pm 8 \\
NSF (n=21) & 27 & 59 & 167 & 0 & 72 & 91 & 119 & 77 & 21 \\
& \pm 10 & \pm 7 & \pm 4 & & \pm 8 & \pm 10 & \pm 13 & \pm 9 & \pm 7 \\
SF (n=12) & 27 & 58 & 165 & 7 & 74 & 92 & 121 & 78 & 16 \\
& \pm 5 & \pm 7 & \pm 9 & \pm 5 & \pm 6 & \pm 8 & \pm 8 & \pm 8 & \pm 6 \\
NSM (n=24) & 31 & 72 & 181 & 0 & 69 & 93 & 125 & 78 & 19 \\
& \pm 9 & \pm 9 & \pm 6 & & \pm 8 & \pm 7 & \pm 8 & \pm 7 & \pm 8 \\
SM (n=24) & 32 & 73 & 178 & 11 & 72 & 100 & 127 & 86 & 15 \\
& \pm 11 & \pm 8 & \pm 6 & \pm 14 & \pm 8 & \pm 8 & \pm 9 & \pm 7 & \pm 6 \\
\hline
\end{tabular}

Data are presented as mean \pm SD. HR: heart rate; MAP: mean arterial pressure; SBP: systolic blood pressure; DBP: diastolic blood pressure; ppb: parts per billion; NSF nonsmoking females; SF: smoking females; NSM: nonsmoking males; SM: smoking males. 
Table 2. - NO levels and characteristics of patients

\begin{tabular}{|c|c|c|c|c|c|c|c|c|}
\hline Patient group & $\begin{array}{l}\text { Age } \\
\text { yrs }\end{array}$ & $\begin{array}{c}\text { Weight } \\
\mathrm{kg}\end{array}$ & $\begin{array}{l}\text { Height } \\
\mathrm{cm}\end{array}$ & $\begin{array}{c}\mathrm{HR} \\
\mathrm{b} \cdot \mathrm{min}^{-1}\end{array}$ & $\begin{array}{c}\text { MAP } \\
\mathrm{mmHg}\end{array}$ & $\begin{array}{c}\mathrm{SBP} \\
\mathrm{mmHg}\end{array}$ & $\begin{array}{c}\mathrm{DBP} \\
\mathrm{mmHg}\end{array}$ & $\begin{array}{l}\mathrm{NO} \\
\mathrm{ppb}\end{array}$ \\
\hline Hypertension $(\mathrm{n}=10)$ & $\begin{array}{r}67 \\
\pm 15\end{array}$ & $\begin{array}{r}74 \\
\pm 23\end{array}$ & $\begin{array}{r}168 \\
\pm 11\end{array}$ & $\begin{array}{r}76 \\
\pm 12\end{array}$ & $\begin{array}{r}102 \\
\pm 10\end{array}$ & $\begin{array}{r}141 \\
\pm 18\end{array}$ & $\begin{array}{l}82 \\
\pm 9\end{array}$ & $\begin{array}{r}13.7 \\
\pm 5.3\end{array}$ \\
\hline Renal failure $b^{*}(n=5)$ & $\begin{array}{r}40 \\
\pm 18\end{array}$ & $\begin{array}{r}64 \\
\pm 17\end{array}$ & $\begin{array}{r}169 \\
\pm 8\end{array}$ & $\begin{array}{r}77 \\
\pm 13\end{array}$ & $\begin{array}{l}112 \\
\pm 13\end{array}$ & $\begin{array}{r}156 \\
\pm 14\end{array}$ & $\begin{array}{r}98 \\
\pm 17\end{array}$ & $\begin{array}{l}20.2 \\
\pm 6.8\end{array}$ \\
\hline Renal failure $d^{*}(n=5)$ & & $\begin{array}{r}62 \\
\pm 16\end{array}$ & & $\begin{array}{r}82 \\
\pm 13\end{array}$ & $\begin{array}{r}103 \\
\pm 19\end{array}$ & $\begin{array}{r}139 \\
\pm 18\end{array}$ & $\begin{array}{r}85 \\
\pm 20\end{array}$ & $\begin{array}{l}19.8 \\
\pm 6.4\end{array}$ \\
\hline Intraop $(\mathrm{n}=10)$ & $\begin{array}{r}46 \\
\pm 22\end{array}$ & $\begin{array}{l}69 \\
\pm 8\end{array}$ & $\begin{array}{r}167 \\
\pm 5\end{array}$ & $\begin{array}{r}80 \\
\pm 10\end{array}$ & $\begin{array}{r}92 \\
\pm 17\end{array}$ & $\begin{array}{l}115 \\
\pm 14\end{array}$ & $\begin{array}{r}80 \\
\pm 19\end{array}$ & $\begin{array}{r}5.6 \\
\pm 2.5\end{array}$ \\
\hline Postop $(n=5)$ & $\begin{array}{r}52 \\
\pm 17\end{array}$ & $\begin{array}{l}70 \\
\pm 8\end{array}$ & $\begin{array}{r}172 \\
\pm 12\end{array}$ & $\begin{array}{r}86 \\
\pm 16\end{array}$ & $\begin{array}{r}91 \\
\pm 10\end{array}$ & $\begin{array}{l}125 \\
\pm 13\end{array}$ & $\begin{array}{r}75 \\
\pm 10\end{array}$ & $\begin{array}{r}10.3 \\
\pm 3.5\end{array}$ \\
\hline Sepsis $(n=3)$ & $\begin{array}{r}64 \\
\pm 14\end{array}$ & $\begin{array}{r}76 \\
\pm 10\end{array}$ & $\begin{array}{r}179 \\
\pm 13\end{array}$ & $\begin{array}{r}71 \\
\pm 53\end{array}$ & $\begin{array}{l}71 \\
\pm 5\end{array}$ & $\begin{array}{l}100 \\
\pm 23\end{array}$ & $\begin{array}{l}56 \\
\pm 8\end{array}$ & $\begin{array}{r}29.3 \\
\pm 24\end{array}$ \\
\hline
\end{tabular}

Data are presented as mean $\pm \mathrm{SD}$. $\mathrm{b}^{*}$ : before dialysis; $\mathrm{d}^{*}$ : during dialysis; intraop: intraoperative patients; postop: postoperative patients; sepsis: septic patients in the intensive care unit. For further abbreviations see legend to table 1.

cases, the normal anaesthesia gas mixture $\left(\mathrm{N}_{2} \mathrm{O}\right.$, enflurane and $\mathrm{O}_{2}$ ) was applied as inhalatory air and NO concentrations were analysed. In 10 postoperative patients on days $3-5$ and in 3 patients with a documented septic syndrome in the intensive care unit, NO was analysed. The body temperatures of septic patients were $37.9,38.0$ and $38.7^{\circ} \mathrm{C}$, respectively. Leucocyte counts were 17.1 , 13.3 and $7.8 \times 10^{9} \cdot l^{-1}$, respectively. All three patients were mechanically-ventilated with standard hospital air and oxygen. NO concentration of the inspired and expired air was assessed. Patients' characteristics are shown in table 2 .

For statistical analyses the unpaired Student's t-test (two tail) was applied. Values of $\mathrm{p} \leq 0.05$ were considered as criteria indicating statistical significance.

\section{Results}

\section{Volunteers}

NO concentration in exhaled air of all volunteers was $18 \pm 8 \mathrm{ppb}$, of nonsmoking females $21 \pm 7 \mathrm{ppb}$ and of smoking females $16 \pm 6 \mathrm{ppb}(\mathrm{p}=0.029)$. Nonsmoking males exhaled $19 \pm 8 \mathrm{ppb}$ and smoking males $15 \pm 6 \mathrm{ppb} \mathrm{p}=0.014)$. The difference between the smoking group (male and female) compared with the nonsmoking group (male and female) was statistically significant $(\mathrm{p}=0.004)$. Mean, systolic and diastolic blood pressures are reported in table 1. A statistically significant difference was found between diastolic blood pressure in smoking and nonsmoking males $(\mathrm{p}=0.0008)$.

\section{Patients}

NO concentration in the exhaled air of patients with documented and treated hypertension was $13.7 \pm 5.3 \mathrm{ppb}$ (table 2, fig. 1), significantly lower $(\mathrm{p}<0.05)$ than values found in healthy volunteers $(18 \pm 8 \mathrm{ppb})$. Male patients with hypertension exhaled $10.2 \pm 2 \mathrm{ppb}$ and females $17 \pm 5$ $\mathrm{ppb}(\mathrm{p}<0.05)$. Mean, systolic and diastolic blood pressure was $102 \pm 10,141 \pm 18$ and $82 \pm 9 \mathrm{mmHg}$, respectively.

NO concentration in the exhaled air of patients with renal failure was $20.2 \pm 6.8 \mathrm{ppb}$ before and $19.8 \pm 6.4 \mathrm{ppb}$ after $1 \mathrm{~h}$ of dialysis.

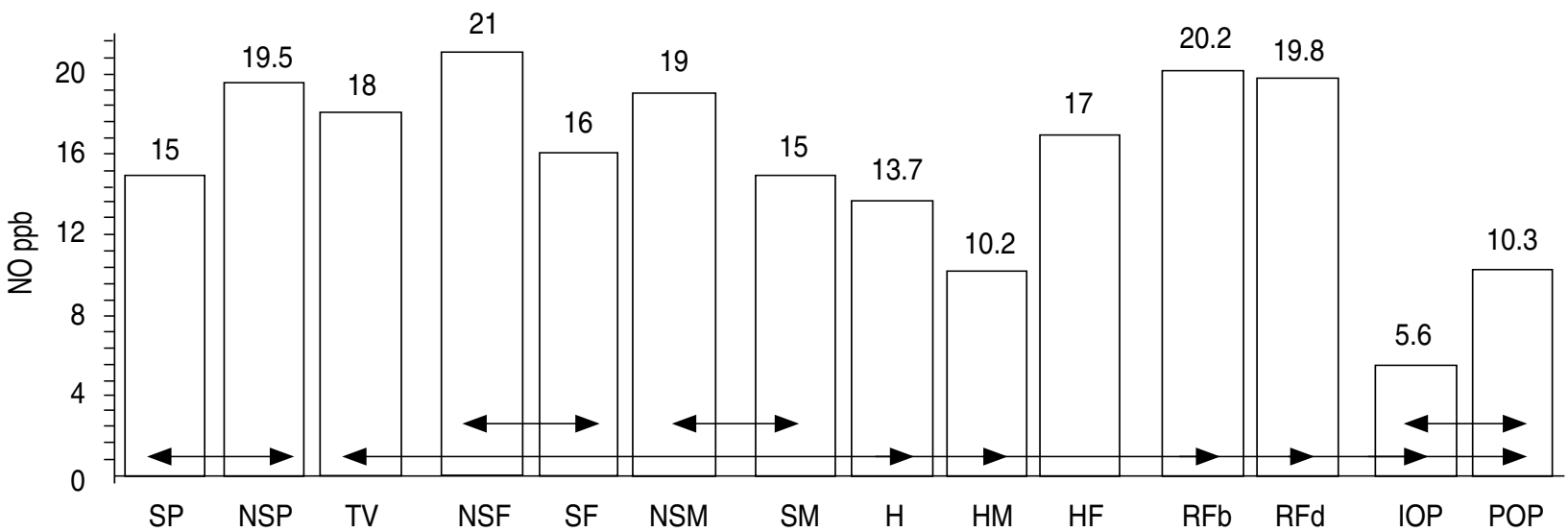

Fig. 1. - Mean NO levels in the exhaled air of the different volunteer and patient groups and relevant statistics. SP: smoking persons; NSP: nonsmoking persons; TV: total volunteers $(\mathrm{n}=81)$; NSF: nonsmoking females, SF: smoking females; NSM: nonsmoking males; SM: smoking males; $\mathrm{H}$ : total hypertensive patients; HM: hypertensive males; HF: hypertensive females; $\mathrm{RFb}$ : renal failure patients before dialysis; $\mathrm{RFd}$ : renal failure patients during dialysis; IOP: intraoperative patients; POP: postoperative patients. Arrows indicate $\mathrm{p} \leq 0.05$. 
Intra- and postoperative $\mathrm{NO}$ exhalation was $5.6 \pm 2.5$ $\mathrm{ppb}$ and $10.3 \pm 3.5 \mathrm{ppb}$. NO concentration of inhaled $\mathrm{N}_{2} \mathrm{O}$, enflurane and $\mathrm{O}_{2}$ mixture was $4 \pm 1 \mathrm{ppb}$.

In patients with sepsis syndrome, purified air was not applicable. Only three patients were involved. The first patient inhaled $7 \mathrm{ppb}$ and exhaled $8 \mathrm{ppb} \mathrm{NO}$; the second patient inhaled $43 \mathrm{ppb}$ and exhaled $55 \mathrm{ppb}$; and the third patient inhaled $36 \mathrm{ppb}$ and exhaled $25 \mathrm{ppb}$. Mean, systolic and diastolic blood pressures were $71 \pm 5,100 \pm 23$ and $56 \pm 8 \mathrm{mmHg}$, respectively.

\section{Discussion}

Endothelium-derived nitric oxide has been found to be a potent endogenous vasodilator with a major role in the regulation of peripheral tone in man [2-4]. Endogenous $\mathrm{NO}$ is present in the exhaled air of rabbits, guinea-pigs and humans [8], but its correlation with the serum NO levels is limited by the known contamination of ambient air with various amounts of NO. In the current study we have been able to produce an NO-free air supply, and to evaluate the levels of endogenous expired NO in healthy controls and individuals with various medical problems.

Nonsmoking healthy females exhaled relatively, but not statistically significantly, more NO than their male counterparts. Blood pressure levels were not significantly different. Cardiovascular risk of females of an age of less than $40 \mathrm{yrs}$ is known to be reduced. An increased endogenous NO production in females may be an important factor indicating a relationship between the lower incidence of cardiovascular disease in woman and endogenous NO concentration.

Cigarette smoking seems to affect the levels of exhaled NO. We observed lower levels of expired NO in the smoking group (male and female) compared to the nonsmoking group (male and female). Smoking males exhaled $4 \mathrm{ppb}$ less NO than nonsmoking males, and smoking females exhaled $5 \mathrm{ppb}$ less NO than nonsmoking females. In view of an increased NO concentration in the inspired air during smoking, lower NO concentration in the expired air in smokers could be explained either by decreased synthesis, a quantitative or qualitative increase of endogenous $\mathrm{NO}$-synthetase-inhibitors, such as $\mathrm{NG}^{\mathrm{G}}$-dimethylarginine or $\mathrm{N}^{\mathrm{G}}$-monomethyl-L-arginine [9], or by increased NO clearance.

In the group of smoking males, a significantly increased diastolic blood pressure was noted compared to nonsmoking males. A large number of studies have confirmed an increased risk for hypertension in smokers, but the exact mechanism remains unclear. The above noted negative correlation between the amount of exhaled endogenous NO and smoking in males may be an important step in the understanding of the pathogenesis of hypertension in this group.

Patients with documented and treated hypertension were older, compared to the volunteer groups. There was a significant difference in mean and systolic blood pressure and exhaled NO concentration $(5.3 \mathrm{ppb})$. Male patients with hypertension exhaled significantly less NO than females ( $10 \pm 2$ versus $17 \pm 5 \mathrm{ppb}$, respectively), and significantly less NO than all volunteer groups. Diastolic blood pressure was similar to volunteers, probably due to medication. A correlation between a decreased endogenous NO production and hypertension may be anticipated. An alternative hypothesis is that the antihypertensive medication influences NO production. A higher NO production due to medication or a more effective response to NO might lower blood pressure. Speculatively, endogenous NO production might be lower without medication. Nevertheless, the opposite might be possible. The medication administered could also lower endogenous NO production directly or via feedback mechanisms. Measurement of endogenously produced NO in untreated patients may be interesting.

In patients with renal failure, an insignificant but increased NO concentration was observed in exhaled air, without changes within an hour of dialysis. Blood pressure was found to be increased prior to dialysis. After one hour of dialysis, blood pressure decreased, probably due to an intended volume loss. These observations are entirely controversial, since increased concentrations of NO-synthetase-inhibitors were found in plasma and urine in patients with renal failure [9]. At the moment, the complexity of this observation needs clarification.

In intraoperative measurements, patients exhaled significantly less NO compared to volunteers. NO concentration of $\mathrm{N}_{2} \mathrm{O}$, enflurane and $\mathrm{O}_{2}$ mixture $(4 \pm 1 \mathrm{ppb})$ was equivalent to $\mathrm{NO}$-free air. A possible explanation for the low NO concentration may be an interaction with $\mathrm{N}_{2} \mathrm{O}$ or enflurane. Another reason may be mechanical ventilation. In trauma patients, analogous low $\mathrm{NO}_{2}^{-}$ $/ \mathrm{NO}_{3}{ }^{-}$levels were observed and remained low even in the presence of sepsis [10]. Considering a surgical procedure as a "trauma", our observations support these findings.

Postoperatively, a significant increase in NO was noted compared to intraoperative levels. As a significant difference to the volunteer group was still observed, the endogenous recovery of NO production may reflect convalescence.

In patients with sepsis syndrome, mean, systolic and diastolic blood pressures were significantly reduced and NO concentration significantly increased. However, the relevance of these results may be confounded by the varying concentrations in inhaled air. As purified air was not applicable in the inhalatory source, the statistically increased NO concentration of exhaled air may be not relevant. On the other hand, human serum levels of nitrite and nitrate ions significantly correlated with blood pressure [11]. High plasma levels of $\mathrm{NO}_{2}-\mathrm{NO}_{3}{ }^{-}$were found in septic patients [10], and NO synthetase inhibitors were successfully utilized in combating hypotension in septic shock [12-14], indicating a role of NO in sepsis.

NO concentration of normal room-air was found to vary critically depending on the number of people and the position of windows in a room (6-192 ppb). Since 1981, the Office for Health and Environments of the City of Zurich performs NO concentration-measurements. As an interesting reference, mean NO concentration over 
the year at one of the most heavily trafficked roads of Zurich in the area of the hospital was $45.5 \mathrm{ppb}$, reaching peaks of up to $170 \mathrm{ppb}$ (Office for Health and Environments of the city of Zurich; personal communication). Against such background variation a standardized purified air for inhalation is mandatory for exact measurements.

The presence of NO in the exhaled air of anaesthetized rabbits, guinea-pigs and five humans has been demonstrated by chemiluminescence, diazotization and mass spectrometry in previous trials $[8,15]$. Volunteers inhaled ambient air through the nose and exhaled $8 \pm 0.8 \mathrm{ppb}$ NO. The findings of this study substantiate NO exhalation. However, under well-controlled conditions we detected a notably higher NO concentration $(18 \pm 8 \mathrm{ppb})$ as well as a significant effect of smoking habit.

At the present time, various efforts are being made to use NO in ppm-concentrations in the treatment of adult respiratory distress syndrome, as well as in pulmonary hypertension. With regard to the calibrations-difference of a factor 1,000 the same NO-analyser is serviceable for NO inlet surveillance.

In view of our findings, efforts to perform NO blood gas analyses may be important. In septic shock, blood gas analyses may provide an important diagnostic tool in evaluating the state of sepsis and shock and determining exact indication and dosage of NO-synthetase-inhibitors [14]. In cardiovascular and hypertension research, effects of different therapies on NO concentrations may have several implications.

Acknowledgements : The authors would like to express their appreciation for the generous help of T. Bürgin, M. Meier and M.F. Probst of the Public Office of Technical Installation and Hygiene of Air for providing facilities for purifying air, A. Meier from the Public Office for Health and Environments of the City of Zurich for advice and W. Strässle and W. Moser from ECO Physics, 8635 Dürnten, $\mathrm{CH}$, for providing the NO-analyser CLD 700 AL. They would also like to thank their colleagues S. Knill, M. Knill, S. Stör, Th. Pasch and U. Binswanger for patient recruitment, G. Uhlschmid for laboratory facilities, P. Schlagenhauf and R. Bottari for manuscript revision, the volunteers for their participation and the nursing staff for their co-operation.

\section{References}

1. Snyder SH, Bredt DS. Biological roles of nitric oxide. Scientific American 1992; 266 (5): 68-71, 74-77.

2. Collier J, Vallance P. Physiological importance of nitric oxide. Br Med J 1991; 302: 1289-1290.

3. Rees DD, Palmer RMJ, Moncada S. Role of endothelium-derived nitric oxide in the regulation of blood pressure. Proc Natl Acad Sci USA 1989; 86: 3375-3378.

4. Vallance P, Collier J, Moncada S. Effects of endothelium-derived nitric oxide on peripheral arteriolar tone in man. Lancet 1989; ii: 997-1000.

5. Rajfer J, Aronson WJ, Bush PA, Dorey FJ, Ignarro LJ. Nitric oxide as a mediator of relaxation of the corpus cavernosum in response to nonadrenergic, noncholinergic neurotransmission. N Engl J Med 1992; 326: 90-94.

6. Cryer A. Scale and diversity of interactions at the vascular endothelium. In: Biochemical Interactions at the Endothelium. Elsevier, 1983; pp. 1-3.

7. Ignarro LJ. Nitric oxide, a novel signal transduction mechanism for transcellular communication. Hypertension 1990; 16: 477-483.

8. Gustafsson LE, Leone AM, Persson MG, Wiklund NP, Moncada S. Endogenous nitric oxide is present in the exhaled air of rabbits, guinea-pigs and humans. Biochem Biophys Res Commun 1991; 181: 852-857.

9. Vallance P, Leone A, Calver A, Collier J, Moncada S. Accumulation of an endogenous inhibitor of nitric oxide synthesis in chronic renal failure. Lancet 1992; 339: 572-575.

10. Ochoa JB, Udekwu AO, Billiar TR, et al. Nitrogen oxide levels in patients after trauma and during sepsis. Ann Surg 1991; 214: 621-626.

11. Takahashi H, Nakanishi T, Nishimura M, Tanaka H, Yoshimura M. Serum levels of nitrite and nitrate ions significantly correlate with blood pressure in women. $J$ Vasc Res 1992; 29: 210.

12. Geroulanos $\mathrm{S}$, Schilling J, Cakmakci $\mathrm{M}$, Jung $\mathrm{H}$, Largiadèr F. Inhibition of NO synthesis in septic shock. Lancet 1992; 339: 435.

13. Petros A, Bennett D, Vallance P. Effect of nitric oxide synthase inhibitors on hypotension in patients with septic shock. Lancet 1991; 338: 1557-1558.

14. Schilling J, Cakmakci M, Bättig U, Geroulanos S. A new approach in the treatment of hypotension in human septic shock by an inhibitor of the nitric oxide synthetase. Int Care Med 1993; 19: 227-231.

15. Persson MG, Gustafsson LE. Ethanol can inhibit nitric oxide production. Eur J Pharmacol 1992; 224: 99-100. 